\title{
Purification Effect Evaluation of the Designed New Volcanic Soil Adsorption Material Containing Bioreactor for Eutrophic Water Treatment
}

\section{Huiling Fu}

Hunan Institute of Technology

Linxian Ding

Zhejiang Normal University

Jingyu Zhai

Ecological Environment Monitoring Station of Yuxi City

Xue-song Wang ( $\nabla$ wlwxs57813@163.com )

China National Analytical Center Guangzhou

\section{Research Article}

Keywords: Eutrophication, volcanic soil, bioreactor, viable but non-culture (VBNC) bacteria, resuscitationpromoting factor (Rpf)

Posted Date: February 15th, 2021

DOI: https://doi.org/10.21203/rs.3.rs-222333/v1

License: (c) (1) This work is licensed under a Creative Commons Attribution 4.0 International License. Read Full License 
1 Purification effect evaluation of the designed new volcanic soil adsorption material

$9{ }^{3}$ College of Geography and Environmental Sciences, Zhejiang Normal University, 10 Jinhua 321004, China.

$11{ }^{4}$ Ecological Environment Monitoring Station of Yuxi city, Department of Ecology and

12 Environment of Yunnan Province, Yuxi 653100, China.

\section{Corresponding Author:}

14 Xuesong Wang Email: wlwxs57813@163.com;

15 Mail address: 100 Xianlie Middle Road, Guangzhou, 510070, China. 


\section{Abstract}

To investigate the purification effect of the new adsorption material containing bioreactor and the critical role of non-culture (VBNC) bacteria in eutrophication

20 ecosystem, major water quality parameters and microbial community were determined and analyzed in prepared eutrophic water for 2 years monitoring. The results showed that removal rates of total phosphorus (TP), total nitrogen (TN), chlorophyll-a (Chl-a) and chemical oxygen demand (COD) ranged of $90.7 \%-95.9 \%, 84.5 \%-92.4 \%, 87.9 \%-$ $95.8 \%$ and $68.3 \%-82.7 \%$, respectively, indicating the designed bioreactor possessed high efficiency in eutrophic water treatment. Although the bioreactor had been operated for 2 years, water from treatment group was more clearer and odorless than control group, exhibiting the long service life of the bioreactor. Stopping operation in August caused the removal rates of major water quality parameters significantly decrease $(p<$ 0.05), revealing stopping operation and high temperature in Summer exerted dual effect on the bioreactor, whereas the impact could be minimized when the bioreactor was running. According to most probable number (MPN) method, the total bacteria under + Rpf treatment were higher than under -Rpf treatment, implying Rpf could resuscitate VBNC bacteria in eutrophication ecosystem. Nine VBNC bacteria were isolated based on the BLAST results of $16 \mathrm{~S}$ rRNA gene, and these bacteria might contribute to eutrophic water treatment based on their functions, such as phosphorus-collecting and denitrification. Those results provided new insights for engineering technology innovation and had benefit in eutrophic water treatment. 
38 Keywords Eutrophication · volcanic soil · bioreactor · viable but non-culture (VBNC)

39 bacteria $\cdot$ resuscitation-promoting factor (Rpf)

40 


\section{Introduction}

In recent decades, aquatic ecosystem has suffered much more serious problems of water eutrophication due to anthropogenic pollution and climate change (Le et al. 2010; Smith 2003; Kosten et al. 2012; Andersen et al. 2020a; Freeman et al. 2020). Eutrophication is often accompanied with rapid occurrences of harmful algal blooms (HABs), especially of chlorella, cyanobacteria (Wang et al. 2019a), and diatoms (Paerl et al. 2016, 2019; Huisman et al. 2018; Woolway et al. 2019; Kim et al. 2020), which threaten other aquatic life and change the color and/or odor of the water body (Vollenweider and Kerekes 1982). Therefore, eutrophic water will finally lose its original functionality, such as aquatic food production and safe-drinking water supply (Huisman et al. 2018). Meanwhile, eutrophication is worldwide environmental problems and have been found in many countries, such as Israel (Geisler et al. 2020), Mexico (Caballero and Vazquez 2020) and USA (Tomasko et al. 2020). It is summarized that over $75 \%$ of the closed water bodies (e.g., lakes, ponds and reservoirs) in Africa, Asia and Latin America have deteriorated largely and encountered some extents of eutrophication since the 1990s (UN-Water 2018).

Evaluating the trophic state of eutrophic water have become a research hotspot in the water ecology community based on several water quality parameters, including total phosphorus (TP), total nitrogen (TN), chlorophyll-a (Chl-a) and chemical oxygen demand (COD) (Chao Rodriguez et al. 2014; Smith and Schindler 2009; Carlson 1977). Previous studies demonstrated that the excessive accumulation of $\mathrm{N}$ and $\mathrm{P}$ in aquatic 
ecosystem is closely related to eutrophication, which, on the one hand, causes greater primary production (Ahlgren et al. 2005; Feuchtmayr et al. 2009) and, on the other hand, hinders the restoration process of the eutrophic ecosystem (Banerjee 2016), thus results in hyper-eutrophication and subsequent water quality deterioration (Ahlgren et al. 2005). At the same time, Chl-a and COD are the key indicators of eutrophic water, which reflect the eutrophication level and the biomass of HABs, and further uncover the intrinsic essence of eutrophication. Therefore, systematically monitoring the trophic state of aquatic ecosystem can effectively evaluate the degree of eutrophication and assess the feasibility of new technical for eutrophic aquatic ecosystem restoration.

Former experiences in eutrophic aquatic ecosystem restorations specifically emphasizing reductions of external nutrient inputs might fail to alleviate the eutrophication (Paerl et al. 2016; Wang et al. 2019a; Lurling and Mucci 2020). As plenty of studies announce that effective removal of excessive $\mathrm{N}$ and $\mathrm{P}$ are of concern for the aquatic ecosystem balance (Gruber and Galloway 2008; Domangue and Mortazavi 2018; Stoliker et al. 2016), the potential impacts from internal nutrient eliminating should be taken into considerations for eutrophic water treatment (Paerl et al. 2019; Wang et al. 2019a; Qin et al. 2020). Physical (Schauser et al. 2003), chemical (Walpersdorf et al. 2004; Wauer et al. 2005) and biological (Xu et al. 2011; Liu et al. 2012; Lu et al. 2014; Petersen et al. 2014; Wu et al. 2015) methods were adopted in extensive researches during the past decades. However, as the reason of financial and labor-intensive challenge, limited to biotic and abiotic restriction and high risk of 
secondary pollution, these methods were difficult to meet the high frequency for eutrophic water treatment, especially for projects with wide distributions (Liang et al. 2014). Hence, new ecological techniques are considered to be the most promising technology depending on its unique features.

Nowadays, numerous studies have reported that new volcanic soil adsorption materials and microbial communities also played important roles in water purification (Ding et al. 2009, 2011; Zhou and Wang 2010). Simultaneously, viable but non-culturable (VBNC) bacteria are frequently found in dyeing workshop (Jin et al. 2017), pharmaceutical waste water (Li et al. 2014) and polychlorinated biphenyls (PCBs) (Su et al. 2014) polluted soils in recent years. The VBNC bacteria can survive under extreme environments by passing into the viable but non-culturable state, and can become culturable under the condition of adding resuscitation promoting factor (Rpf) cultivation (Ding et al. 2011; Mukamolova et al. 2002; Serpaggi et al. 2012). Previous studies have certified a number of VBNC bacteria could be recovered by Rpf, including high $\mathrm{G}+\mathrm{C}$ gram-positive bacteria, low $\mathrm{G}+\mathrm{C}$ gram-positive bacteria and several gram-negative bacteria (Ding et al. 2011; Yu et al. 2015). However, whether VBNC bacteria surviving in eutrophic water and weather VBNC bacteria possessing certain environmental purification function had not been reported to the best of our knowledge. In this study, a new volcanic soil adsorption material containing multi-stage tandem type bioreactor has been designed. The purification effect of eutrophic water (TP, TN, Chl-a and COD) and the functional microbial communities, especially VBNC 
bacteria, have been assessed and analyzed based on seasonal changing. This work has benefit in further understanding the microbial clustering in sewage treatment system and provide new insights for enhancing the efficiency of eutrophic water treatment by improving the engineering technology.

\section{Materials and methods}

\section{Preparation of eutrophic water}

The water sample in the bioreactor was composed of synthetic nutrient matrix mixed with raw water from a eutrophic lake (Xinyue lake, Jinhua, China), and the ratio of synthetic nutrient matrix and raw water was 97:3 (V/V). The initial compositions of synthetic nutrient matrix were as follows: beef extract $(1.000 \mathrm{~g})$, yeast extract $(1.000 \mathrm{~g})$, $\mathrm{K}_{2} \mathrm{HPO}_{4}(0.272 \mathrm{~g}), \mathrm{KH}_{2} \mathrm{PO}_{4}(0.456 \mathrm{~g})$, water $(1.0 \mathrm{~L})$. The quality parameters of water sample were TP $22.4 \mathrm{mg} / \mathrm{L}$, TN $16.5 \mathrm{mg} / \mathrm{L}, \mathrm{Chl}-\mathrm{a} 218.5 \mu \mathrm{g} / \mathrm{L}$ and COD $202.4 \mathrm{mg} / \mathrm{L}$. The water sample $(100 \mathrm{~L})$ recycling treatment in the bioreactor was denoted as treatment group, and the other water sample $(100 \mathrm{~L})$ placement under natural condition was denoted as control group.

\section{The novel adsorption material}

The novel adsorption material in the bioreactor was a mixture of several efficient adsorption materials, which made from volcanic soil. It had granular appearance and its diameter ranged from 2 to $4 \mathrm{~mm}$ (Fig. 1) (Ding et al. 2009). The surface area of $1 \mathrm{~L}$ novel adsorption material can be up to $21,476 \mathrm{~m}^{2}$ and is suit for microbial habitat as its 
micron-scale holes. Therefore, when sewage flowed through the bioreactor, the new adsorption materials could effectively absorb chemicals and enrich microbial doubly.

\section{Construction and operation of the bioreactor}

The self-designed bioreactor was composed of 9 tower tanks (volume of tower tank was $550 \mathrm{~mL}$ ), and every 3 of them were in series (Fig. 2). The water sample flowed into the bottom of the first tower tank and transferred into the bottom of the subsequent tower tank from the top of the former tower tank after flowing through the filter plate and the new adsorption material (200 g). Then the bioreactor treated water returned into reservoir through reflux pipe and merged for next purification.

Based on eutrophication preferred to occur in spring, summer, autumn and less outbreak in winter, 3 running and 2 stopping stages were designed during the experiment. Two years stable operation scheme of the bioreactor was enacted as follows: 1 year running before summer - stopping in summer - running in autumn - stopping in winter - running after winter. The details for actual operation and the environmental temperature were listed in Table 1.

\section{Water quality parameters detection}

The major water quality parameters of water samples were detected about every 3 months both in treatment and control group. The TP, TN, Chl-a and COD were measured according to ammonium molybdate spectrophotometric method, alkaline potassium persulfate digestion UV spectrophotometric method, spectrophotometric 
method and $\mathrm{HACH}$ method, respectively. The removal rates were calculated through the following equation: $\mathrm{R}=\left(1-\mathrm{C} / \mathrm{C}_{\mathrm{o}}\right) \times 100 \%$, where $\mathrm{R}$ was the removal rate $(\%)$ of major water quality parameter, $\mathrm{C}$ and $\mathrm{C}_{\mathrm{o}}$ were the concentrations of major water quality parameter in treatment and control group, respectively. Three replicates were set for control and treatment group of water samples. T-test was performed using SPSS 19.0 software. The results were expressed as the mean \pm SD (standard deviation).

\section{TP detection}

The water sample was adjusted to neutral and then $25 \mathrm{~mL}$ water sample was transferred into a $50 \mathrm{~mL}$ plug scale tube. About $4 \mathrm{~mL} \mathrm{~K}_{2} \mathrm{~S}_{2} \mathrm{O}_{8}$ solution was added into the plug scale tube for digestion in a autoclave. Two hours later, when temperature dropped to $80^{\circ} \mathrm{C}$, the plug scale was took out and diluted to the tick mark with ultrapure water. Ascorbic acid $(1 \mathrm{~mL})$ was added to the diluted digestion solution and then mixed completely. Thirty seconds later, $2 \mathrm{~mL}$ molybdate solution were added into the plug scale and placed for $15 \mathrm{~min}$ at room temperature. The absorbance was determined at the wavelength of $700 \mathrm{~nm}$. The content of TP was determined according to the following formula:

$$
\mathrm{TP}(\mathrm{mg} / \mathrm{L})=\mathrm{m} / \mathrm{V} \text {; }
$$

where " $\mathrm{m}$ " was the P content in water sample $(\mu \mathrm{g})$, "V" was the volume of water sample (mL).

\section{TN detection}



transferred into a $25 \mathrm{~mL}$ colorimetric tube. About $5 \mathrm{~mL}$ alkaline potassium persulfate 166 solution was added into the colorimetric tube for digestion in a autoclave. Thirty minutes later, when pressure dropped to $80^{\circ} \mathrm{C}$, the colorimetric tube was took out and cooled down. Hydrochloric acid (1 mL) was added into the digestion solution and then diluted to the tick mark with ultrapure water. About $5 \mathrm{~mL}$ diluted solution were added to cuvette. The absorbance was determined at the wavelength of 200 and $275 \mathrm{~nm}$, and the absorbance $\mathrm{A}=\mathrm{A}_{220}-\mathrm{A}_{275}$. The content of $\mathrm{TN}$ was determined according to the following formula: sample (mL).

\section{Chl-a detection}

Water sample $(1000 \mathrm{~mL})$ and $1 \% \mathrm{MgCO}_{3}(5 \mathrm{~mL})$ were mixed completely. About $200 \mathrm{~mL}$ mixtrue was filtered with 0.45 um glass fiber filter film. When filtering finished, the filter film was clamped out with clean tweezers. After folded in half twice, the filter determined the absorbance at the wavelength of 649,665 and $750 \mathrm{~nm}$. The content of

$\mathrm{TN}(\mathrm{mg} / \mathrm{L})=\mathrm{m} / \mathrm{V}$

where "m" was the $\mathrm{N}$ content in water sample $(\mu \mathrm{g})$, "V" was the volume of water film was put into a centrifuge tube with $10 \mathrm{~mL} 95 \%$ ethanol and incubated at $4^{\circ} \mathrm{C}$ for 20 h. Following the centrifuge tube were $3000 \mathrm{rpm}$ centrifuged for $15 \mathrm{~min}$ and then Chl-a was determined according to the following formula:

$$
\mathrm{Chl}-\mathrm{a}=\left(13.7 *\left(\mathrm{~A}_{665}-\mathrm{A}_{750}\right)-5.76 *\left(\mathrm{~A}_{649}-\mathrm{A}_{750}\right)\right) *(\mathrm{E} / \mathrm{F}) * \mathrm{~L} ;
$$



was the width of cuvette (mm).

\section{COD detection}

Water sample (2.5 mL), $\mathrm{K}_{2} \mathrm{Cr}_{2} \mathrm{O}_{7}$ solution $(1.5 \mathrm{~mL})$ and $\mathrm{Ag}_{2} \mathrm{SO}_{4}$ solution $(3.5 \mathrm{~mL})$ were mixed completely in $\mathrm{HACH}$. Then the mixture was digested under $150^{\circ} \mathrm{C}$ for $2 \mathrm{~h}$ and cooled down for $30 \mathrm{~min}$. The absorbance was determined by DR1010.

\section{Most probable number (MPN) method for bacteria identification in the bioreactor}

Bacteria were isolated from the bioreactor using the most probable number (MPN) method (McCrady et al. 1915). The VBNC bacteria were isolated by adding Rpf protein coming from Micrococcus luteus culture supernatant (Ding et al. 2012; Su et al. 2014). The liquid medium consisted of peptone $5.0 \mathrm{~g}$, yeast extract $0.5 \mathrm{~g}$, glucose $5.0 \mathrm{~g}$, sodium chloride $2.5 \mathrm{~g}$, distilled water 1.0 L, $\mathrm{pH}$ 7.0-7.2, including the active Rpf (+Rpf) and inactive $\operatorname{Rpf}(-\mathrm{Rpf})$, respectively, where the volume ratio was 4:1. Three replicates were set for adding $+\mathrm{Rpf}$ and $-\mathrm{Rpf}$ treatments, respectively. The bacteria solution was prepared by mixing weighted $1 \mathrm{~g}$ novel volcanic soil adsorption material and $9 \mathrm{~mL} 0.9 \%$ normal saline. Bacteria solution $(0.25 \mathrm{~mL})$ and liquid medium $(2.25 \mathrm{~mL})$ was mixed. Then, the mixture was gradually diluted from $10^{-1}$ to $10^{-7}$ with the prepared liquid medium. The bacteria solution with different dilutions were incubated at $30^{\circ} \mathrm{C}$ and the turbidity of bacteria solution was measured by microplate reader at the wavelength of $660 \mathrm{~nm}\left(\mathrm{OD}_{660}\right)$. When the flora was in stationary phase, turbidity or non-turbidity of 
the cultivate tube was recorded as positive or negative, respectively. The total number of bacteria in + Rpf and - Rpf treatments were determined by the MPN table (Fig. S1).

\section{Rpf effect and VBNC bacteria status evaluation}

$V_{R}$ was the ratio of total amount of bacteria in + Rpf treatment and in $-R p f$ treatment, and was used to evaluate the activity abundance of Rpf. $V_{R}$ greater than 5 indicated that there had dominant bacteria in VBNC state, which was sensitive to Rpf.

212 from $10^{-1}$ to $10^{-6}$ in $+\operatorname{Rpf}$ and $-\operatorname{Rpf}$ treatments were also carried out to identify the 213 presence of VBNC bacteria. Genomic DNA was extracted using the MiniBEST

214 Bacterial Genomic DNA Extraction Kit Ver.2.0 (Takara, Dalian, China), and 16S rDNA 215 V3 region was amplified by the following primers: F, 5'-CGCCCGCCG 216 CGCGCGGCGGGCGGGGCGGGGGCACGGGGGGCCTACGGGAGGCAGCAG-3'

217 and R, 5'-ATTACCGCGGCTGCTGG-3'. The PCR amplified procedure was shown in 218 Table S1.

219 The PCR product was detected by $1 \%$ agarose gel electrophoresis (AGE) and 220 purified. The qualified PCR products was separated by denaturing gradient gel 221 electrophoresis (DGGE) with $8 \%$ polyacrylamide and 40\%-60\% denaturing solution.

\section{Constructing the phylogenetic trees of the isolated bacteria}


ACGA-3'. The sequences of 16S rRNA gene were blasted in NCBI (http://www. ncbi.nlm.nih.gov/) and EzTaxon server (http://www.eztaxon.org/) to identify the genrea of bacteria. The phylogenetic tree of all isolated bacteria was constructed by MEGA 5.0. The neighbor-joining method was selected in the instruction of phylogenetic tree (Saitou and Nei 1987). The evolutionary distance matrix was calculated using Kimura's two-parameter method (Kimura 1980). And the bootstrap values were set for 1000 replications (Felsenstein 1985).

\section{Results}

\section{Removal effect of TP in the bioreactor}

The TP concentrations in water sample (both in control and treatment groups) and

235 the removal rate of the bioreactor were shown in Fig. 3. The TP concentrations ranged 236 of $0.91-2.06 \mathrm{mg} / \mathrm{L}$ and $20.09-23.38 \mathrm{mg} / \mathrm{L}$ in treatment group and control group, 237 respectively. All of the TP concentrations in treatment group were significantly lower than in control group $(p<0.05)$, no matter the bioreactor was running or stopping. The

239 TP removal rates of the bioreactor ranged from $90.7 \%$ to $95.9 \%$, indicating the 240 bioreactor could efficiently reduce the TP concentration of eutrophic water. The TP 241 removal rate in February of TY was $92.8 \%$ and was significantly lower than in 242 November of SY (94.2\%) and May of TY (94.4\%) $(p<0.05)$, showing bioreactor 243 stopping operation affected TP elimination. Meanwhile, the TP removal rate in August 244 of SY was $90.7 \%$ and was significantly lower than other detection months $(p<0.05)$, 
exhibiting the bioreactor stopping and the high temperature were the two key factors for influencing TP removing. What's more, the TP removal rate in March of SY $(95.9 \%)$ were significantly higher than the other detection months $(p<0.05)$, implying the bioreactor had the best purification effect in Spring.

\section{Removal effect of $\mathrm{TN}$ in the bioreactor}

The TN concentrations in water sample (both in control and treatment groups) and the removal rate of the bioreactor were shown in Fig. 4. The TN concentrations ranged of $1.32-2.44 \mathrm{mg} / \mathrm{L}$ and $13.86-17.50 \mathrm{mg} / \mathrm{L}$ in treatment group and control group, respectively. All of the TN concentrations in treatment group were significantly lower than in control group $(p<0.05)$, no matter the bioreactor was running or stopping. The $\mathrm{TN}$ removal rates of the bioreactor ranged from $84.5 \%$ to $92.4 \%$, indicating the bioreactor could effectively reduce the $\mathrm{TN}$ concentration of eutrophic water. The TN removal rate in February of TY was $85.8 \%$ and was significantly lower than in November of SY $(89.6 \%)$ and May of TY $(91.8 \%)(p<0.05)$, showing the bioreactor stopping operation affected TN elimination. Meanwhile, the TN removal rate in August of SY was $84.5 \%$ and was significantly lower than other detection months $(p<0.05)$, exhibiting the bioreactor stopping and the high temperature also influenced $\mathrm{TN}$ removing. Simultaneously, the TN removal rate in March of SY (92.4\%) were significantly higher than the other detection months, except in September of FY (91.9\%) and May of TY (91.8\%), suggesting the bioreactor had the better purification effect in 


\section{Removal effect of Chl-a in the bioreactor}

267

The Chl-a concentrations in water sample (both in control and treatment groups) and the removal rate of the bioreactor were shown in Fig. 5a. The Chl-a concentrations ranged of $8.41-28.46 \mu \mathrm{g} / \mathrm{L}$ and $200.11-234.38 \mu \mathrm{g} / \mathrm{L}$ in treatment group and control group, respectively. All of the Chl-a concentrations in treatment group were significantly lower than in control group $(p<0.05)$, no matter the bioreactor was running or stopping. The Chl-a removal rates of the bioreactor ranged from $87.9 \%$ to 95.8\%, indicating the bioreactor could efficient reduce the Chl-a concentration of eutrophic water. The Chl-a removal rate in February of TY was $93.7 \%$ and was significantly lower than in November of SY $(95.2 \%)$ and May of TY $(95.8 \%)(p<0.05)$, showing bioreactor stopping operation affected Chl-a elimination. Meanwhile, the Chl-a removal rate in August of SY was $87.9 \%$ and was significantly lower than other detection months $(p<0.05)$, exhibiting the bioreactor stopping and the high temperature exerted doubly effect on Chl-a removing. Meanwhile, the Chl-a removal rate in March of SY $(95.6 \%)$ were significantly higher than the other detection months, except in November of SY (95.2\%) and May of TY (95.8\%), suggesting the bioreactor had the better purification effect in Spring and Autumn. The real comparison of water sample between control and treatment group was showed in Fig. $5 b$.

\section{Removal effect of COD in the bioreactor}

The COD concentrations in water sample (both in control and treatment groups) 
ranged of $32.13-45.11 \mathrm{mg} / \mathrm{L}$ and $185.26-208.42 \mathrm{mg} / \mathrm{L}$ in treatment group and control group, respectively. All of the COD concentrations in treatment group were significantly lower than in control group $(p<0.05)$, no matter the bioreactor was running or stopping. The COD removal rates of the bioreactor ranged from $68.3 \%$ to $82.7 \%$, indicating the bioreactor could efficiently reduce the COD concentration of eutrophic water. The COD removal rate in February of TY was $78.6 \%$ and was significantly lower than in November of SY $(82.7 \%)$ and May of TY $(81.3 \%)(p<0.05)$, showing bioreactor stopping operation affected COD elimination. Meanwhile, the COD removal rate in August of SY was $68.3 \%$ and was significantly lower than other detection months ( $p<$ 0.05), exhibiting the bioreactor stopping and the high temperature severely affected COD cleaning. Meanwhile, the COD removal rate in March of SY (82.5\%) was significantly higher than the other detection months, except in November of SY (82.7\%), suggesting the bioreactor had the better purification effect in Spring and Autumn.

\section{The $\mathrm{OD}_{660}$ value of bacteria solution in $+\mathrm{Rpf}$ and $-\mathrm{Rpf}$ treatment}

In present study, bacteria were cultivated by using MPN method. The $\mathrm{OD}_{660}$ values in the stationary phase of bacteria solution were listed in Table 2. No significant difference of $\mathrm{OD}_{660}$ values were observed between $+\mathrm{Rpf}$ and $-\mathrm{Rpf}$ treatment under the dilution of $10^{-1}$ and $10^{-3}$, respectively. However, the $\mathrm{OD}_{660}$ values under the dilution from $10^{-4}$ to $10^{-6}$ were continuously higher in $+\mathrm{Rpf}$ treatment than in $-\mathrm{Rpf}$ treatment, revealing the number, species or number and species of bacteria was increased under the adjunction of Rpf. The total number of bacteria attached on the novel volcanic soil 
adsorption material were $2.4 \times 10^{9}$ and $1.1 \times 10^{8}$ cells/g in + Rpf and - Rpf treatments,

309 respectively. The $\mathrm{V}_{\mathrm{R}}$ value was 21.8, indicating there had dominant bacteria in VBNC

310 state, which were sensitive to Rpf.

\section{The DGGE analysis of bacteria solution in $+\mathbf{R p f}$ and $-\mathbf{R p f}$ treatment}

The PCR results of $16 \mathrm{~S}$ rDNA V3 region in MPN culture system (same as the above experiment) were showed in Fig. 7. The target bands were clear and bright, indicating the PCR product could be used for DGGE analysis after purification. than -Rpf treatment, especially under the dilution from $10^{-2}$ to $10^{-6}$ (Fig. 8), which were in accordance with the $\mathrm{OD}_{660}$ values, indicating $\mathrm{Rpf}$ had a certain effect on promoting bacteria resuscitation in the eutrophic water treatment system. What's more, the bands under the dilution of $10^{-3}, 10^{-5}$ and $10^{-6}+\mathrm{Rpf}$ treatment appeared on the top of the lanes, whereas the bands under the dilution of $10^{-2}+\mathrm{Rpf}$ treatment appeared at the bottom of the lane, suggesting the microbial would compete with each other and would not both take function under the same dilution.

Blast results of 16s rDNA PCR products

In this study, 24 strains of bacteria were isolated from the bioreactor (Table 3). The isolated bacteria were belonged to 11 genera, including Bacillus, Brevibacillus, 
belonged to Low GC gram-positive (50\%), followed by gram-negative bacteria (42\%) and poor in high GC gram-positive bacteria (8\%). Therefore, Rpf not only promoted the resuscitation of gram-positive bacteria, but also activated gram-negative bacteria in the bioreactor. At the same time, 9 strains of VBNC bacteria were native from 4 genrea, including Bacillus (3), Burkholderia (2), Enterobacter (2) and Pseudomonas (2). The phylogenetic tree was constructed and showed in Fig. 9.

\section{Discussion}

\section{Efficient purification capacity of the volcanic soil containing bioreactor}

Based on former researches, TP, TN, Chl-a and COD were the major water quality parameters for evaluating the trophic state of eutrophic water (Chao Rodriguez et al. 2014; Smith and Schindler 2009, Carlson 1977). Excessive accumulation of N and P in aquatic ecosystem not only caused greater primary production (Ahlgren et al. 2005, Feuchtmayr et al. 2009), but also slowed down the restoration process of water ecosystem (Banerjee 2016), thus resulted in eutrophication (Ahlgren et al. 2005) and accompanied with occurrences of HABs. Simultaneously, Chl-a and COD were the key indicators for reflecting the degree of eutrophication. Therefore, systematically monitoring the trophic state of eutrophic water could effectively assess the purification effect of the designed multi-stage tandem type bioreactor. In this study, 2 years systematically monitoring job were carried out by real-time detection the 4 major water quality parameters. The results showed that the self-designed bioreactor could efficient 
removal TP, TN, Chl-a and COD, no matter the bioreactor was running or stopping. The average removal rates of $\mathrm{TP}, \mathrm{TN}, \mathrm{Chl}-\mathrm{a}$ and $\mathrm{COD}$ reached to $93.6 \%, 89.6 \%, 93.4 \%$ and $78.5 \%$, respectively. In addition, regardless the high efficient removal rate of the major water quality parameters, the bioreactor had a long service life. Until now, although the bioreactor has been operated for more than 2 years, the water from treatment group was clear and odorless, whereas the water from control group was cloudy and odorous.

\section{Season-changing and stopping operation affect the removal rate of the bioreactor}



the same time, water temperature and nutrient availability were believed to be two of

371 the most important factors in facilitating occurrences of HABs (Beaulieu et al. 2013;

372 Rigosi et al. 2014; Tong et al. 2019a). Therefore, understanding the potential impacts of eutrophication and water temperatures and their interactions with seasonal changing was crucial to assess the designed bioreactor. In present study, a continuously running process of the bioreactor was designed in the first year, whereas two stopping status (Summer and Winter) were designed in the next year, so that we could comprehensivly evaluate the effect of season changing on the purification of the bioreactor. According to the results, the removal rates of the 4 major water quality parameters in February of TY were significantly lower than in November of SY and in May of TY $(p<0.05)$, indicating stopping operation could significantly influence the purification effect of the bioreactor, despite eutrophication was less likely to occur in Winter. What's more, the removal rates of the 4 major water quality parameters in August of SY were operation and the high temperature in Summer could doubly affect the removal rates of the bioreactor. Warming in surface waters was the most direct response of water body in summer (Rigosi et al. 2014; Piccolroaz et al. 2020), where was usually the place for phytoplankton living. As the overall function of aquatic ecosystems alteration in Summer, such as biochemical transformations of nutrients (Wu et al. 2017; Ding et al. 

al. 2016; Freeman et al. 2020). From the results, although stopping operation and high temperature could affect the removal rates of the bioreactor, there had little influence on the purification effect when the bioreactor was running, showing the good effect of the bioreactor. Meanwhile, the removal rates of the 4 major water quality parameters in March and December of SY were always higher than the other detection months, suggesting the bioreactor had the better purification effect in Spring and Autumn.

\section{Potential ability of VBNC bacteria in eutrophication ecosystem restoration}

It has been reported that the eutrophication level was well associated with the activities of bacteria in aquatic ecosystem, such as nitrogen-fixing bacteria, nitrifying bacteria and denitrifying bacteria (Fosso-Kankeu and Mulaba-Bafubiandi 2014). Meanwhile, the nitrogen absorbed and utilized by microbial and algae would dissolve concentration increasing. In the Lake Taihu, China, $\mathrm{NO}_{3}{ }^{-} \mathrm{N}$ concentration in Spring over 10 times higher than in summer (Xu et al. 2010, 2015; Wang et al. 2019b), and had confirmed that nitrification rates were highest in March and lowest in July based on stable-isotope techniques (Hampel et al. 2018), which implied microbial could positive take part in eutrophic water treatment. In this study, the total bacteria count in $+\mathrm{Rpf}$ treatment group was obviously higher than in -Rpf treatment group, which were in consistent with the $\mathrm{OD}_{660}$ values and the DGGE results of MPN culture system, 410 indicating adding active Rpf could efficiently facilitate microbial resuscitation. What's 
411 more, the VR value was 21.82, implying there had dominant VBNC bacteria in

412 eutrophic water treatment system, which was sensitive to Rpf. Meanwhile, 24 bacteria

413 were isolated from the novel volcanic soil adsorption material, and were native from 11

414 genera. Nine isolated strains belonged to VBNC bacteria based on the BLAST results of

415 16S rDNA gene, and were annotated into 4 genera, including genera Bacillus,

416 Burkholderia, Enterobacter and Pseudomonas. Numerous researches had certified that

417 bacteria from genrea Bacillus owned the ability of algae-lysing and heterotrophic

418 nitrification (Kim et al. 2005). Whereas bacteria from Pseudomonas possessed the

419 ability of phosphorus-collecting and participated in sewage treatment as their function

420 of nitrification and denitrification (Li et al. 2015; Srinandan et al. 2011). In addition,

421 Bacillus and Pseudomonas are two crucial genrea in heavy metals (HMs) treatment as

422 their high adsorption and transformation ability for heavy metal ions, such as $\mathrm{Co}^{2+}, \mathrm{Ni}^{2+}$

423 and $\mathrm{Pb}^{2+}$ (Giridhar Babu et al. 2013; Haroun et al. 2017). Meantime, Burkholderia and

424 Enterobacter bacteria were reported to purify sewage and to promote organic matter

425 degradation (Mcneely et al. 2009; Tiar et al. 2018), respectively. Therefore, the verified

426 VBNC bacteria of the 4 genera potential had the functions of degrading organic matter,

427 denitrification, phosphorus-collecting and algae-lysing, which had benefit in eutrophic

428 water treatment. Although the definite function of the isolated bacteria remained

429 limitation to the best of our knowledge, the role VBNC bacteria provide new insights

430 for eutrophication ecosystems restoration.

\section{Conclusion}



by detection the major water quality parameters for 2 years. We found that, first of all, 434 the bioreactor revealed high removal rates of TP, TN, Chl-a and COD, indicating the 435 efficient purification ability of the volcanic soil containing bioreactor. Secondly, 436 although stopping operation and high temperature in Summer affected purification 437 effect, the impact could be minimized when the bioreactor was running. Thirdly, the 438 bioreactor had a long service life, which meet the demand for long period treatment. 439 Fourthly, Rpf could resuscitate the VBNC bacteria in eutrophication ecosystem, and 440 these bacteria could potential participate in eutrophic water treatment. These results had 441 benefit in new engineering technology innovation for aquatic ecosystems restoration, 442 and provided new insights for water environment treatment by VBNC bacteria.

\section{Ethical Approval}

$444 \quad$ Not applicable.

\section{Consent to Participate}

$446 \quad$ Not applicable.

\section{Consent to Publish}

Not applicable. 
Huiling Fu: Conceptualization, Methodology, Writing - original draft.

Linxian Ding: Conceptualization, Supervision, Writing-Review \& Editing.

Jingyu Zhai: Methodology, Investigation, Formal analysis, Visualization.

\section{Funding}

The study was supported by the Public Welfare Technology Application Research

Project of Zhejiang Science and Technology Department (2017C33046).

\section{Competing Interests}

The authors declare that they have no competing interests.

\section{Availability of data and materials}

460

The datasets used or analyzed during this study are available from the corresponding author on reasonable request.

\section{Acknowledgments} research. 
Ahlgren J, Tranvik L, Gogool A, Waldeback M, Markides K, Rydin E (2005): Depth attenuation of biogenic phosphorus compounds in lake sediment measured by 31PNMR. Environ Sci Technol 39, 867e872.

470

Andersen IM, Williamson TJ, Gonzalez MJ, Vanni MJ (2020): Nitrate, ammonium, and phosphorus drive seasonal nutrient limitation of chlorophytes, cyanobacteria, and diatoms in a hyper-eutrophic reservoir. Limnol Oceanogr 65(5), 962-978.

Banerjee S (2016): Network analysis reveals functional redundancy and keystone taxa amongst bacterial and fungal communities during organic matter decomposition in an arable soil. Soil Biol Biochem 97, 188-198.

Beaulieu M, Pick F, Gregory-Eaves I (2013): Nutrients and water temperature are significant predictors of cyanobacterial biomass in a 1147 lakes data set. Limnol Oceanogr 58(5), 1736-1746.

Caballero M, Vazquez G (2020): Mixing patterns and deep chlorophyll a maxima in an eutrophic tropical lake in western Mexico. Hydrobiologia doi.org/10.1007/s10750-020-04367-y.

Carlson RE (1977): A trophic state index for lakes1 Limnology and oceanography. Limnol Oceanogr 22, 361-369.

Chao Rodriguez Y, el Anjoumi A, Dominguez Gomez JA, Rodriguez Perez D, Rico E (2014): Using Landsat image time series to study a small water body in Northern 
Ding LX, Hirose T, Yokota A (2009): Four novel Arthrobacter species isolated from filtration substrate. Int J Syst Evol Micr 59, 856-862.

Ding LX, Su XM, Yokota A (2011): Research progress of VBNC bacteria. Acta Microbiologica Sinica 51(7), 858-862.

Ding LX, Zhang PH, Hong HC, Lin HJ, Yokota A (2012): Cloning and expression of Micrococcus luteus IAM 14879 Rpf and its role in the recovery of the VBNC state in Rhodococcus sp. DS471. Acta Microbiologica Sinica 52(1), 77-82.

Ding S, Chen M, Gong M, Fan X, Qin B, Xu H, Gao S, Jin Z, Tsang DCW, Zhang C (2018): Internal phosphorus loading from sediments causes seasonal nitrogen limitation for harmful algal blooms. Sci Total Environ 625, 872-884.

Domangue RJ, Mortazavi B (2018): Nitrate reduction pathways in the presence of excess nitrogen in a shallow eutrophic estuary. Environ Pollut 238, 599e606.

Felsenstein J (1985): Confidence limits on phylogenies: an approach using the bootstrap. Evolution 39, 783-791.

Feuchtmayr H, Moran R, Hatton K, Connor L, Heyes T, Moss B, Harvey I, Atkinson D (2009): Global warming and eutrophication: effects on water chemistry and autotrophic communities in experimental hypertrophic shallow lake mesocosms. J Appl Ecol 46, 713e723.

Fosso-Kankeu E, Mulaba-Bafubiandi AF (2014): Implication of plants and microbial metalloproteins in the bioremediation of polluted waters: a review. Phys Chem 
508 Freeman EC, Creed IF, Jones B, Bergström AK (2020): Global changes may be 509 promoting a rise in select cyanobacteria in nutrient-poor northern lakes. Global $510 \quad$ Change Biol 26, 4966-4987.

511 Geisler E, Bogler A, Bar-Zeev E, Rahav E (2020): Heterotrophic Nitrogen Fixation at the Hyper-Eutrophic Qishon River and Estuary System. Front Microbio 11, 1370.

Giridhar Babu A, Kim JD, Oh BT (2013): Enhancement of heavy metal phytoremediation by Alnus firma with endophytic Bacillus thuringiensis GDB-1. J Hazard Mater 250-251, 477-483.

Gruber N, Galloway JN (2008): An Earth-system perspective of the global nitrogen cycle. Nature 451, 293e296.

Hampel JJ, McCarthy MJ, Gardner WS, Zhang L, Xu H, Zhu G, Newell SE (2018): Nitrification and ammonium dynamics in Taihu lake, China: seasonal competition for ammonium between nitrifiers and cyanobacteria. Biogeoscience. 15(3), 733-748.

Haroun AA, Kamaluddeen KK, Alhaji I, Magaji Y, Oaikhena EE (2017): Evaluation of Heavy Metal Tolerance Level (MIC) and Bioremediation Potentials of Pseudomonas aeruginosa Isolated from Makera-Kakuri Industrial Drain in Kaduna, Nigeria. Eur Exp Biol 7(5), 28.

Hua MH, Ao YS, Yang XE, Li TQ (2008) Treating eutrophic water for nutrient reduction using an aquatic macrophyte (Ipomoea aquatica Forsskal) in a deep flow 
technique system. Agr Water Manage 95(5), 607-615.

Hua MH, Yuan JH, Yang XE, He ZL (2010) Effects of temperature on purification of eutrophic water by floating eco-island system. Acta Ecologica Sinica 30, 310-318.

Huisman J, Codd GA, Paerl HW, Ibelings BW, Verspagen JMH, Visser PM (2018): Cyanobacterial blooms. Nat Rev Microbiol 16(8), 471-483.

Jenny JP, Anneville O, Arnaud F, Baulaz Y, Bouffard D, Domaizon I, Bocaniov SA, Chèvre N, Dittrich M, Dorioz JM, Dunlop ES, Dur G, Guillard J, Guinaldo T, Jacquet S, Jamoneau A, Jawed Z, Jeppesen E, Krantzberg G, Lenters J, Leoni B, Meybeck M, Nava V, Nõges T, Nõges P, Patelli M, Pebbles V, Perga ME, Rasconi S, Ruetz CR, Rudstam L, Salmaso N, Sapna S, Straile D, Tammeorg O, Twiss MR, Uzarski DG, Ventelä AM, Vincent WF, Wilhelm SW, Wängberg SA, Weyhenmeyer GA (2020): Scientists' warning to humanity: rapid degradation of the world's large lakes. J Great Lakes Res 46(4), 686-702.

Jin Y, Gan G, Yu X, Wu D, Zhang L, Yang N, Hu J, Liu Z, Zhang L, Hong H, Yan X, Liang Y, Ding L, Pan Y (2017): Isolation of Viable but Non-culturable Bacteria from Printing and Dyeing Wastewater Bioreactor Based on Resuscitation Promoting Factor. Curr Microbiol 74(7), 787-797.

Kim JK, Park KJ, Cho KS, Nam SW, Park TJ, Bajpai R (2005): Aerobic nitrification-denitrification by heterotrophic Bacillus strains. Bioresour Technol 96(17), 1897-1906.

Kim K, Mun H, Shin H, Park S, Yu C, Lee J, Yoon Y, Chung H, Yun H, Lee K, Jeong 

Nitrogen stimulates microcystis-dominated blooms more than phosphorus in river conditions that favor non-nitrogen-fixing genera. Environ Sci Technol 54 (12),

Kosten S, Huszar VLM, Becares E, Costa LS, van Donk E, Hansson LA, Jeppesenk E, Kruk C, Lacerot G, Mazzeo N, De Meester L, Moss B, Lurling M, Noges T, Romo S, Scheffer M (2012): Warmer climates boost cyanobacterial dominance in shallow lakes. Global Change Biol 18(1), 118-126.

Le C, Zha Y, Li Y, Sun D, Lu H, Yin B (2010): Eutrophication of lake waters in China: cost, causes, and control. Environ Manage 45, 662-668.

Li C, Yang J, Wang X, Wang E, Li B, He R, Yuan H (2015): Removal of nitrogen by heterotrophic nitrification-aerobic denitrification of a phosphate accumulating bacterium Pseudomonas stutzeri YG-24. Bioresour Technol 182, 18-25.

Li M, Wu YJ, Yu ZL, Sheng GP, Yu HQ (2009): Enhanced nitrogen and phosphorus removal from eutrophic lake water by Ipomoea aquatica with low-energy ion implantation. Water Res 43, 1247-1256.

Li SH, Jin Y, Cheng J, Park DJ, Kim CJ, Hozzein WN, Wadaan MAM, Shu WS, Ding LX, Li WJ (2014): Gordonia jinhuaensis sp. nov. a novel actinobacterium, isolated 

Leeuw 106(2), 347-56.

Liang X, Zhu S, Ye R, Guo R, Zhu C, Fu C, Tian G, Chen Y (2014): Biological thresholds of nitrogen and phosphorus in a typical urban river system of the Yangtz delta, China. Environ Pollut 192, 251-258.

Liu X, Huang SL, Tang T, Liu XG, Scholz M (2012): Growth characteristics and nutrient removal capability of plants in subsurface vertical flow constructed wetlands. Ecol Eng 44, 189-198.

Lu H, Yuan Y, Campbell DE, Qin P, Cui L (2014): Integrated water quality, emergy and economic evaluation of three bioremediation treatment systems for eutrophic water. Ecol Eng 69, 244-254.

Lurling M, Mucci M (2020): Mitigating eutrophication nuisance: in-lake measures are becoming inevitable in eutrophic waters in the Netherlands. Hydrobiologia doi:10.1007/s10750-020-04297-9.

McCrady MH (1915): The numerical interpretation of fermentation-tube results. J Infect Dis $17,183-212$.

Mcneely D, Moore JE, Elborn JS, Millar BC, Dooley JSG (2009): Isolation of Burkholderia cenocepacia and Burkholderia vietnamiensis from human sewage. Int J Environ Heal R 19(2), 157-162.

Mukamolova GV, Turapov OA, Kazarian K, Telkov M, Kaprelyants AS, Kell DB, Young M (2002): The rpf gene of Micrococcus luteus encodes an essential secreted 

growth factor. MolMicrobiol 46(3), 611-621.

Paerl HW, Gardner WS, Havens KE, Joyner AR, McCarthy MJ, Newell SE, Qin B, Scott JT (2016): Mitigating cyanobacterial harmful algal blooms in aquatic ecosystems impacted by climate change and anthropogenic nutrients. Harmful Algae 54, 213-222.

Paerl HW, Havens KE, Xu H, Zhu G, McCarthy MJ, Newell SE, Scott JT, Hall NS, Otten TG, Qin B (2019): Mitigating eutrophication and toxic cyanobacterial blooms in large lakes: the evolution of a dual nutrient ( $\mathrm{N}$ and $\mathrm{P}$ ) reduction paradigm. Hydrobiologia doi:10.1007/s10750-019-04087-y.

Petersen JK, Hasler B, Timmermann K, Nielsen P, Torring DB, Larsen MM, Holmer M (2014): Mussels as a tool for mitigation of nutrients in the marine environment. Mar Pollut Bull 82(1-2), 137-143.

Piccolroaz S, Woolway RI, Merchant CJ (2020): Global reconstruction of twentieth century lake surface water temperature reveals different warming trends depending on the climatic zone. Clim Change 160(3), 427-442.

Qin B, Zhou J, Elser JJ, Gardner WS, Deng J, Brookes JD (2020): Water depth underpins the relative roles and fates of nitrogen and phosphorus in lakes. Environ Sci Technol 54(6), 3191-3198.

Rigosi A. Carey CC, Ibelings BW, Brookes JD (2014): The interaction between climate warming and eutrophication to promote cyanobacteria is dependent on trophic state and varies among taxa. Limnol Oceanogr 59(1), 99-114. 
612 Saitou N, Nei M (1987): The neighbor-joining method: a new method for reconstructing 613 phylogenetic trees. Mol Biol Evol 4(4), 406-425.

614 Schauser I, Lewandowski J, Hupfer M (2003): Decision support for the selection of an appropriate in-lake measure to influence the phosphorus retention in sediments. Water Res 37(4), 801-12.

617

Serpaggi V, Remize F, Recorbet G, Gaudot-Dumas E, Sequeira-Le Grand A, Alexandre H (2012): Characterization of the "viable but nonculturable" (VBNC) state in the wine spoilage yeast Brettanomyces. Food Microbiol 30(2), 438-447.

Smith VH (2003): Eutrophication of freshwater and coastal marine ecosystems a global problem. Environ Sci Pollut R 10, 126-139.

Smith VH, Schindler DW (2009): Eutrophication science: where do we go from here? Trends Ecol Evol 24, 201-207.

Srinandan CS, Shah M, Patel B, Nerurkar AS (2011): Assessment of denitrifying bacterial composition in activated sludge. Bioresour Technol 102, 9481-9489.

Stoliker DL, Repert DA, Smith RL, Song B, LeBlanc DR, McCobb TD, Conaway CH, Hyun SP, Koh DC, Moon HS (2016): Hydrologic controls on nitrogen cycling processes and functional gene abundance in sediments of a groundwater flow-through lake. Environ Sci Technol 50, 3649e3657.

Su X, Liu Y, Hu J, Ding L, Shen C (2014): Optimization of protein production by Micrococcus luteus for exploring pollutant-degrading uncultured bacteria. SpringerPlus 3(1), 117. 
Tiar A, Askarne L, Ait addi E, Assabbane A, Boubaker H (2018): Decolorization of the azo dye methyl red by an isolated bacterium Enterobacter hormaechei strain CUIZ1. J Mater Environ Sci 9(10), 2822-2830.

Tomaskoa D, Aldersonb M, Burnesc R, Heckerd J, Iadevaiad N, Leveroneb J, Raulersone G, Sherwood E (2020): The effects of Hurricane Irma on seagrass meadows in previously eutrophic estuaries in Southwest Florida (USA). Mar Pollut Bull 156, 111247.

Tong Y, Xu X, Zhang S, Shi L, Zhang X, Wang M, Qi M, Chen C, Wen Y, Zhao Y, Zhang W, Lu X (2019): Establishment of season-specific nutrient thresholds and analyses of the effects of nutrient management in eutrophic lakes through statistical machine learning. J Hydrol 578, 124079.

UN-Water Paris (2018): The United Nations World Water Development Report 2018: Nature-Based Solutions for Water. UNESCO.

Vollenweider R, Kerekes J (1982): In: Eutrophication of Waters. Monitoring, Assessment and Control. Organization for Economic Co-Operation and Development (OECD), Paris p. 156.

Walpersdorf E, Neumann T, Stüben D (2004): Efficiency of natural calcite precipitation compared to lake marl application used for water quality improvement in an eutrophic lake. Appl Geochem 19(11), 1687-1698.

Wang J, Fu Z, Qiao H, Liu F (2019a): Assessment of eutrophication and water quality in the estuarine area of Lake Wuli, Lake Taihu, China. Sci Total Environ 650, 
Wang M, Xu X, Wu Z, Zhang X, Sun P, Wen Y, Wang Z, Lu X, Zhang W, Wang X, Tong Y (2019b): Seasonal pattern of nutrient limitation in a eutrophic lake and quantitative analysis of the impacts from internal nutrient cycling. Environ Sci Technol 53(23), 13675-13686.

Wauer G, Gonsiorczyk T, Kretschmer K, Casper P, Koschel R (2005): Sediment treatment with a nitrate-storing compound to reduce phosphorus release. Water Res 39(2-3), 494-500.

Woolway RI, Merchant CJ (2019): Worldwide alteration of lake mixing regimes in response to climate change. Nat Geosci 12(4), 271-276.

Wu HL, Huo YZ, Hu M, Wei ZL, He PM (2015): Eutrophication assessment and bioremediation strategy using seaweeds co-cultured with aquatic animals in an enclosed bay in China. Mar Pollut Bull 95(1), 342-349.

Wu Z, Liu Y, Liang Z, Wu S, Guo H (2017): Internal cycling, not external loading, decides the nutrient limitation in eutrophic lake: a dynamic model with temporal Bayesian hierarchical inference. Water Res 116, 231-240.

Xu D, Gao Z, Zhang X, Qi Z, Meng C, Zhuang Z, Ye N (2011): Evaluation of the potential role of the macroalga Laminaria japonica for alleviating coastal eutrophication. Bioresour Technol 102, 9912-9918.

Xu H, Paerl HW, Qin B, Zhu G, Gao G (2010): Nitrogen and phosphorus inputs control phytoplankton growth in eutrophic Lake Taihu, China. Limnol Oceanogr 55(1), 
676 Xu H, Paerl HW, Qin B, Zhu G, Hall NS, Wu Y (2015): Determining critical nutrient 677 thresholds needed to control harmful cyanobacterial blooms in eutrophic Lake 678 Taihu, China. Environ Sci Technol 49(2), 1051-1059.

679 Yu XY, Zhang L, Ren B, Yang N, Liu M, Liu XT, Zhang LX, Ding LX (2015): 680 Arthrobacter liuii sp nov., resuscitated from Xinjiang desert soil. Int J Syst Evol $681 \quad$ Micr 65, 896-901.

682 Zhao F, Xi S, Yang X, Yang W, Li J, Gu B, He Z (2012): Purifying eutrophic river 683 waters with integrated floating island systems. Ecol Eng 40, 53-60.

684

685

686

687

688 689

Zhou XH, Wang GX (2010): Nutrient concentration variations during Oenanthe javanica growth and decay in the ecological floating bed system. J Environ Sci 22(11):1710-1717.

Zuo SP, Wan K, Ma SM (2014): Environmental restoration effects of Ranunculus sceleratus L. in a eutrophic sewage system. Biochem Syst Ecol 55, 34-40. 


\section{Figures}

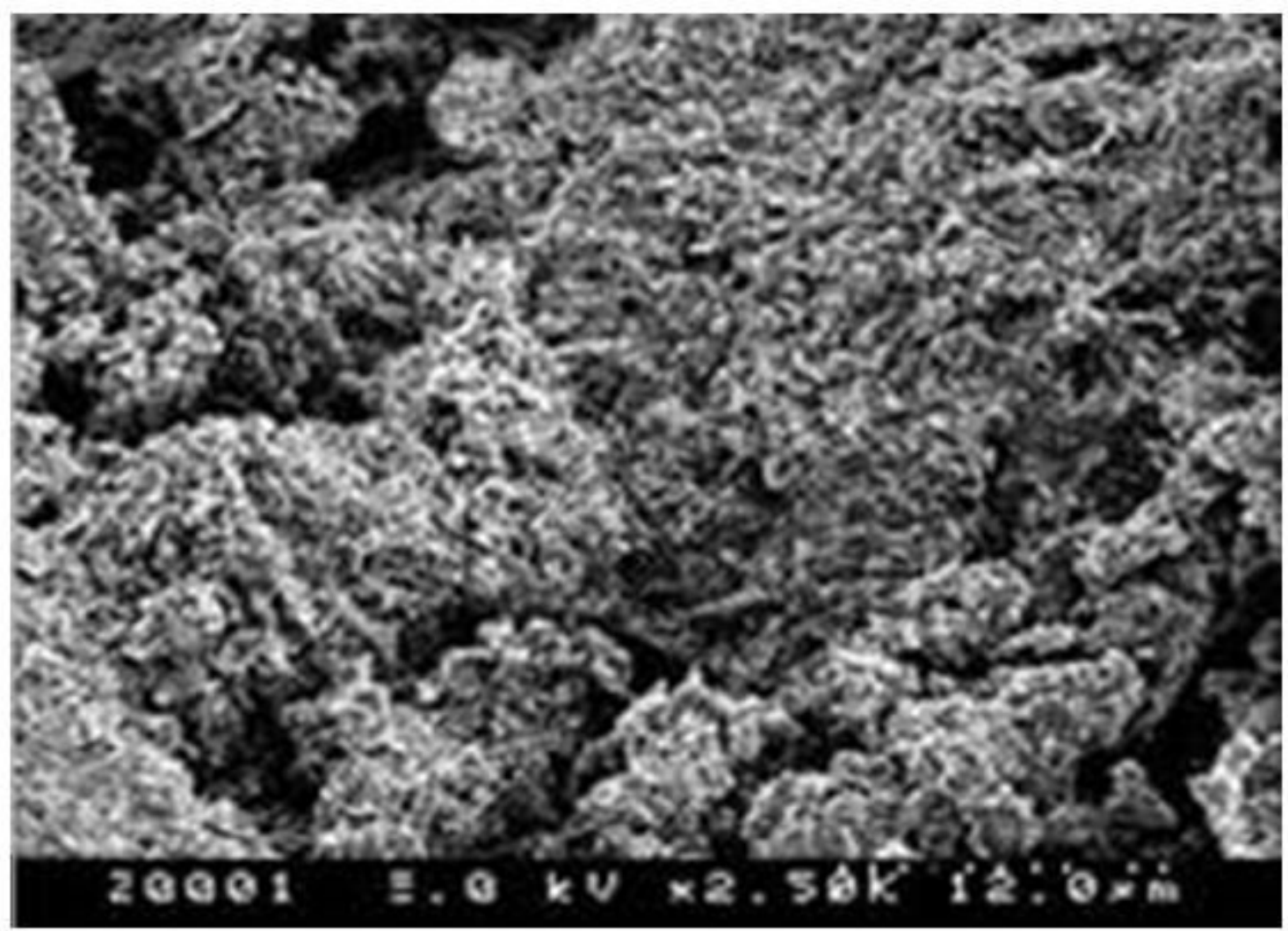

\section{Figure 1}

Scanning electron microscope (SEM) image of new adsorption material 


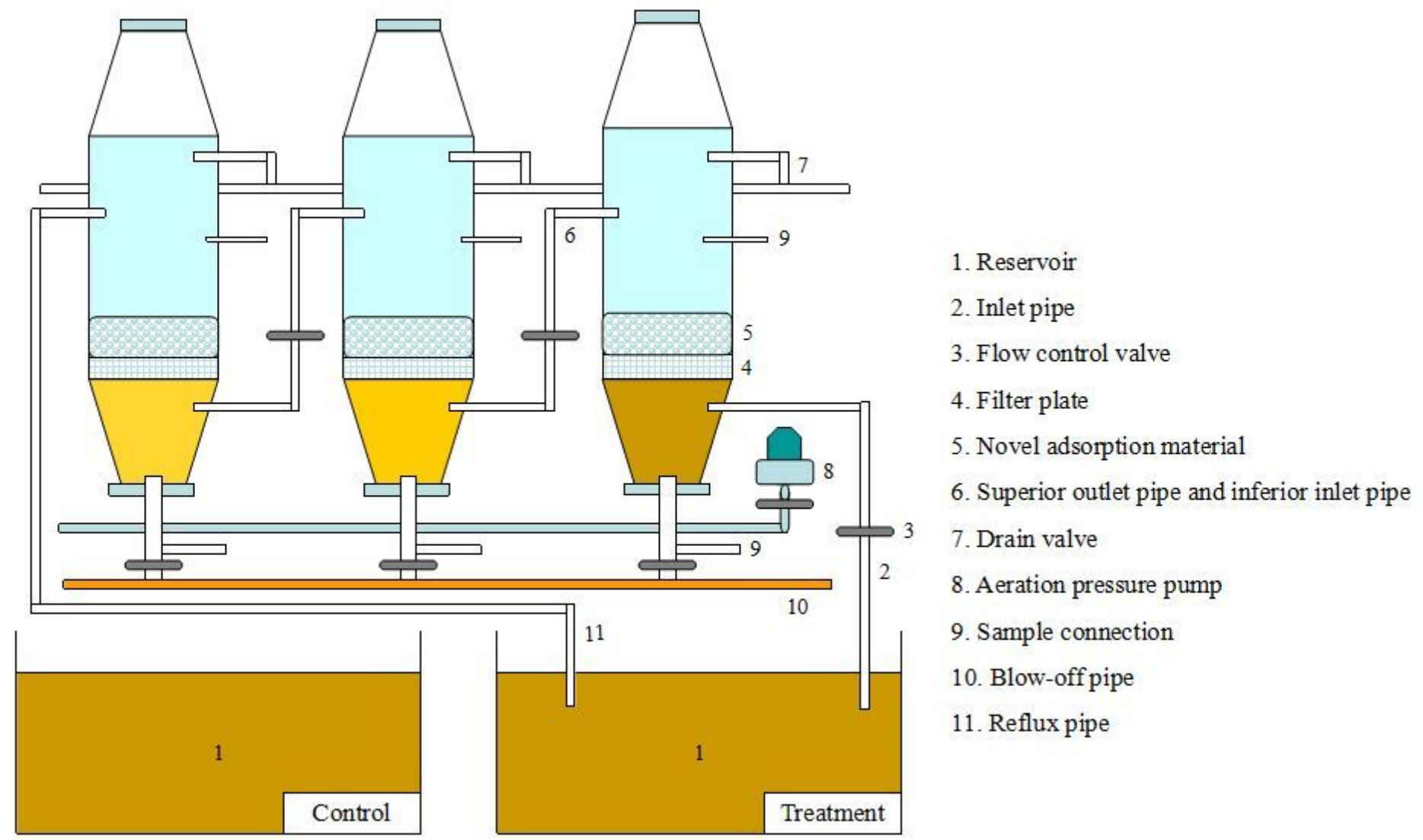

Figure 2

Design diagram of the bioreactor 


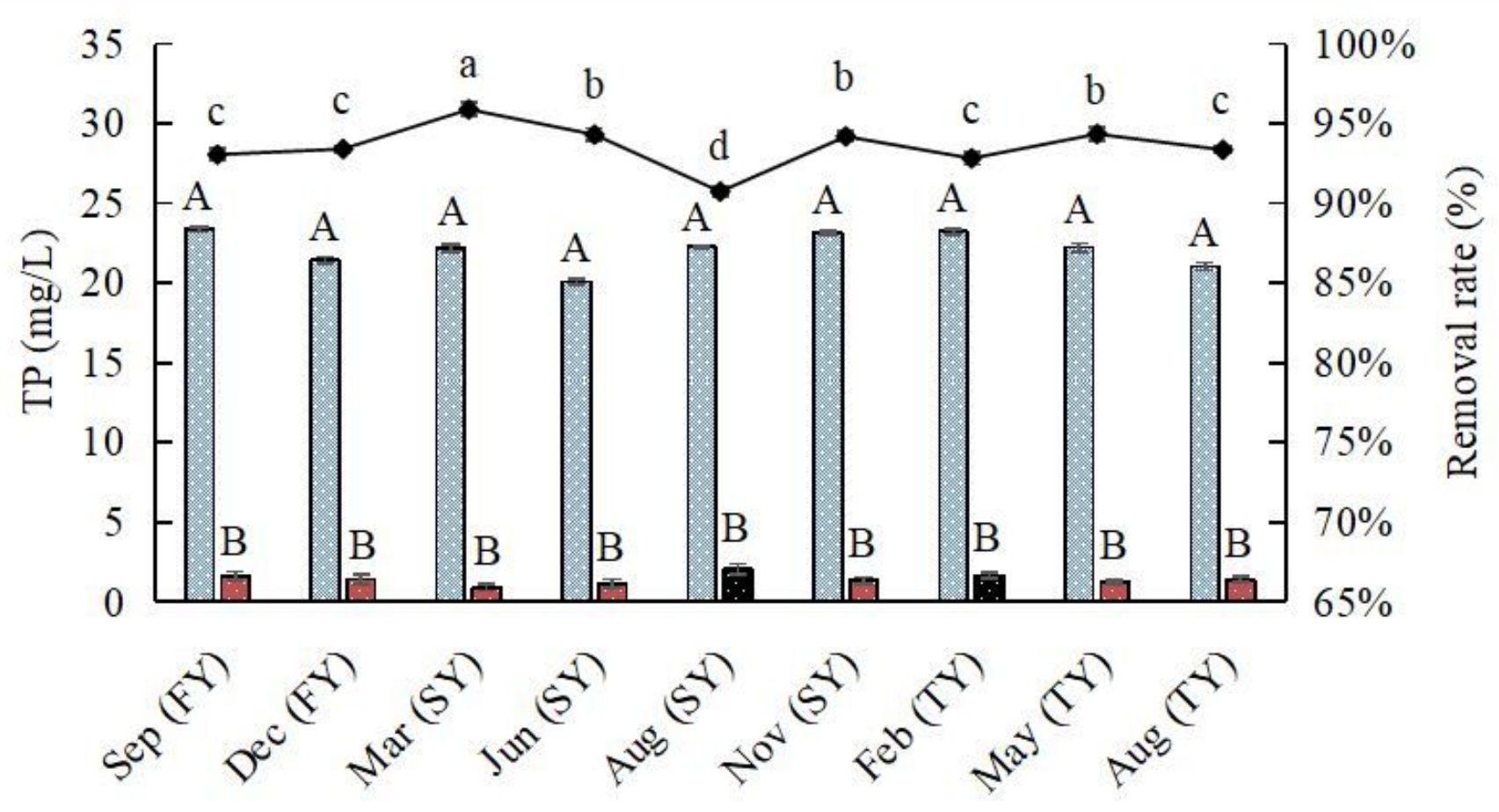

$\square$ Control group $\square$ Treatment group $\rightarrow-$ Removal rate of bioreactor

\section{Figure 3}

The TP concentrations in control and treatment group as well as the TP removal rate of the bioreactor. Different small letters indicate significant differences at $p<0.05$ level of LSD test of the removal rates under different detection months. Different capital letters indicate significant differences at $p<0.05$ level between control and treatment groups at the same detection month. The black bar in treatment group represented the TP concentrations of water sample when the bioreactor was stopping. 


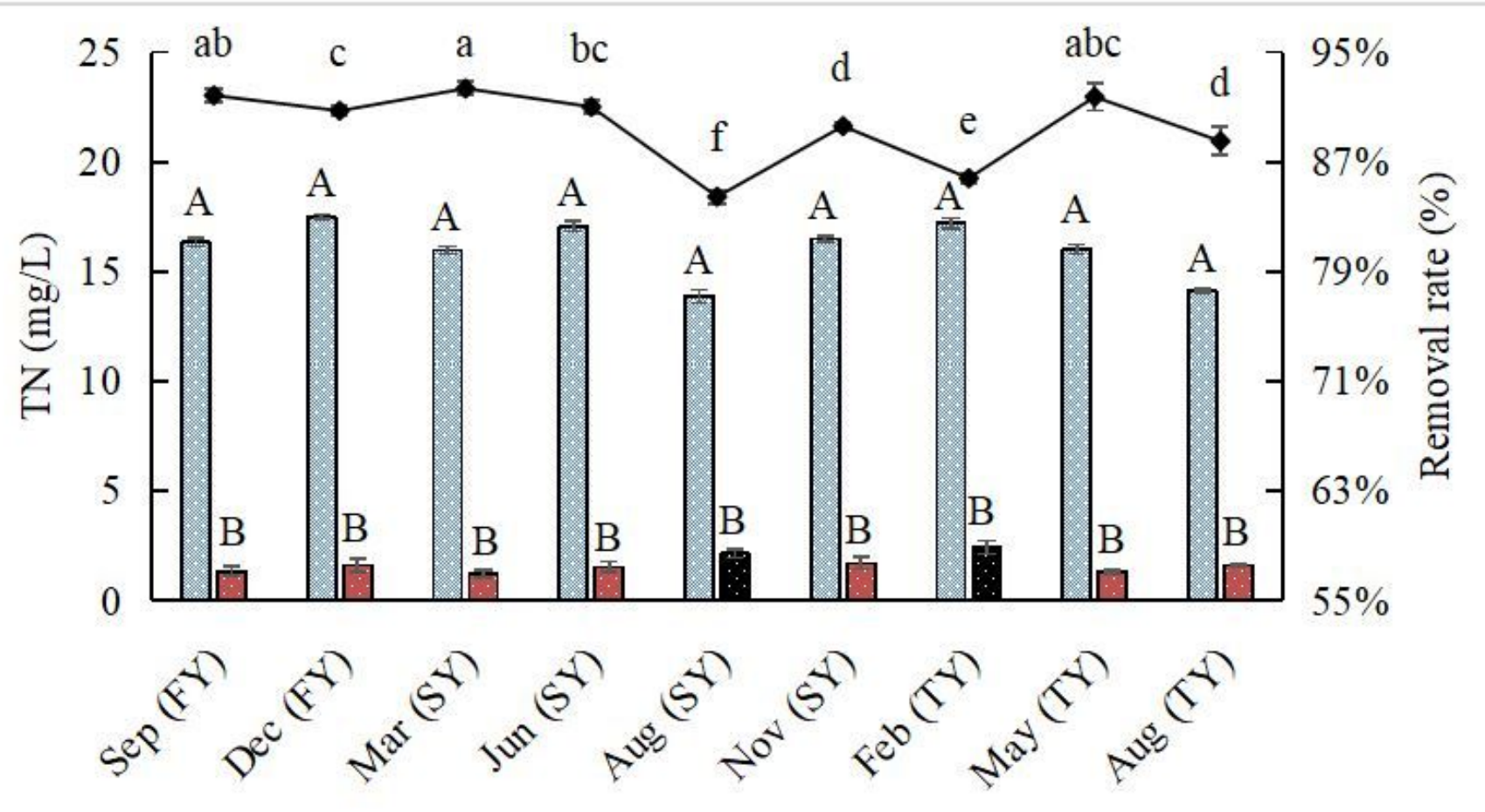

$\square$ Control group $\square$ Treatment group $\longrightarrow-$ Removal rate of bioreactor

\section{Figure 4}

The TN concentrations in control and treatment group as well as the TN removal rate of the bioreactor. Different small letters indicate significant differences at $p<0.05$ level of LSD test of the removal rates under different detection months. Different capital letters indicate significant differences at $p<0.05$ level between control and treatment groups at the same detection month. The black bar in treatment group represented the TN concentrations of water sample when the bioreactor was stopping.

a

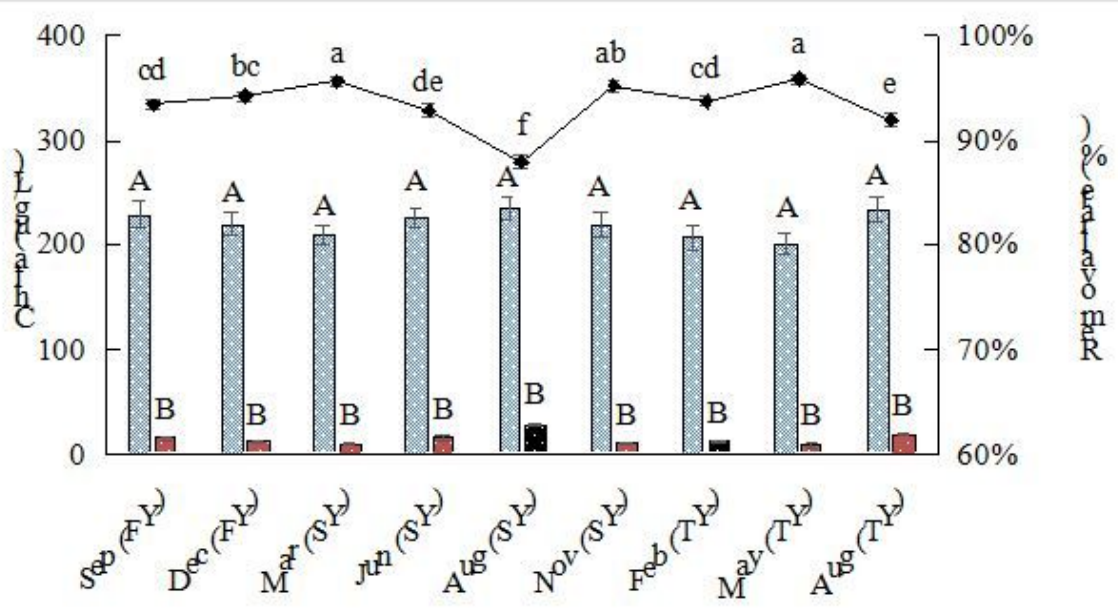

b

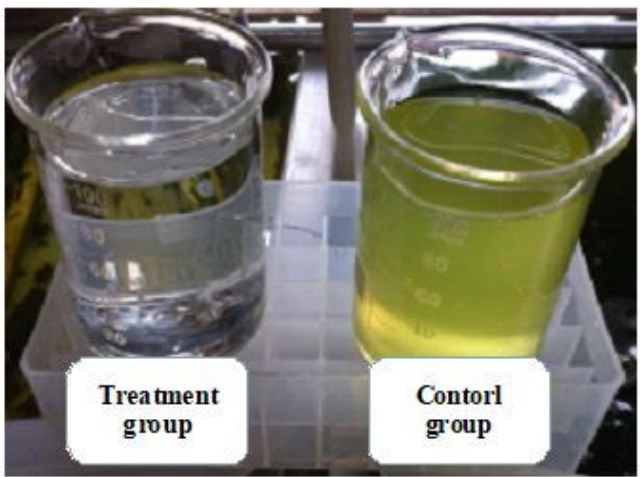

Control group $\cdots$ Treatment group $\longrightarrow$ Removal rate of bioreactor 
Figure 5

a) The Chl-a concentrations in control and treatment group as well as the Chl-a removal rate of the bioreactor; b) The real comparison between control and treatment group. Different small letters indicate significant differences at $p<0.05$ level of LSD test of the removal rate under different detection months. Different capital letters indicate significant differences at $p<0.05$ level between control and treatment groups at the same detection month. The black bar in treatment group represented the TN concentrations of water sample when the bioreactor was stopping.

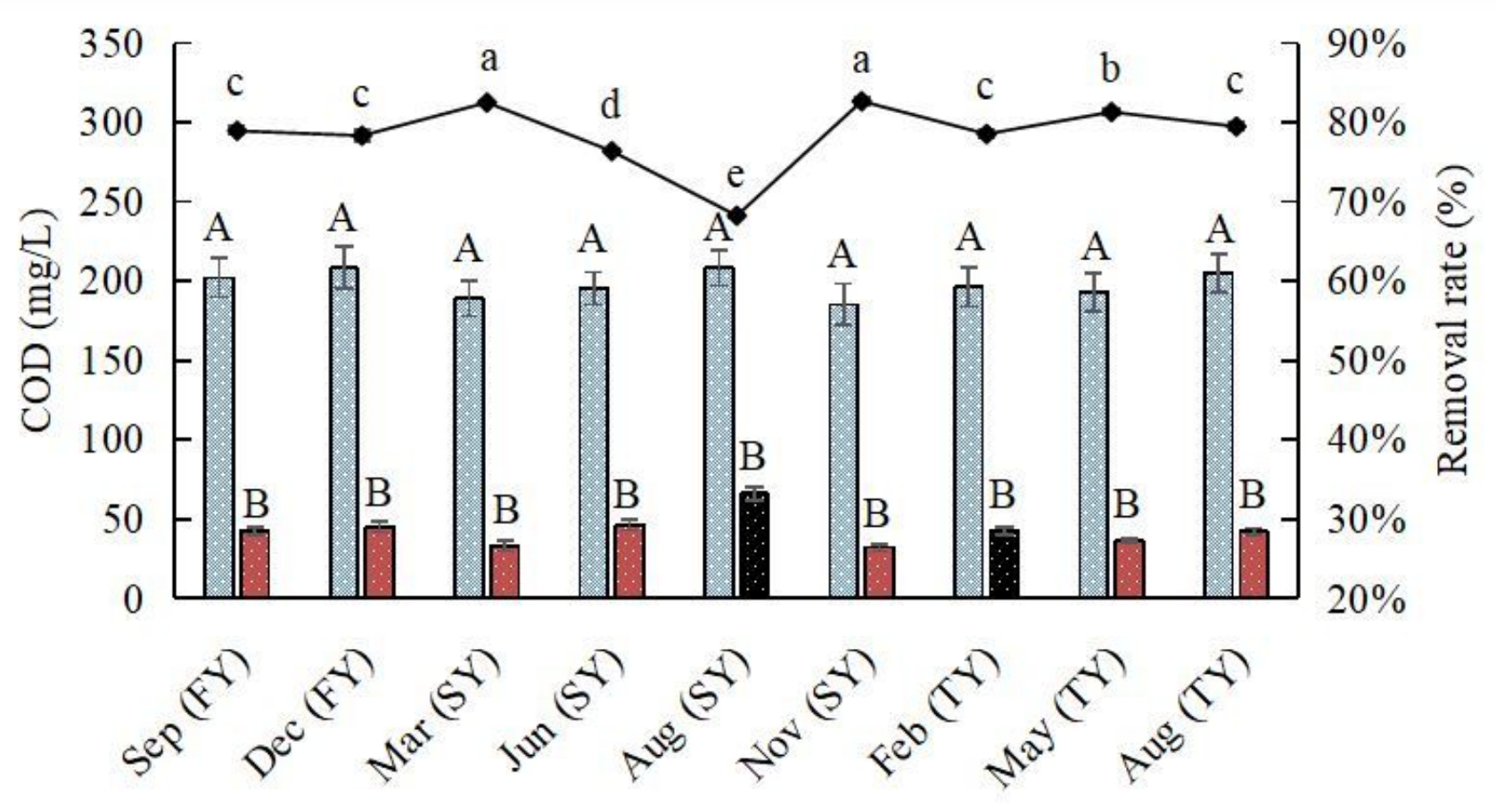

$\square$ Control group $\square$ Treatment group $\multimap-$ Removal rate of bioreactor

Figure 6

The COD concentrations in control and treatment group as well as the COD removal rate of the bioreactor. Different small letters indicate significant differences at $p<0.05$ level of LSD test of the removal rate under different detection months. Different capital letters indicate significant differences at $p<0.05$ level between control and treatment groups at the same detection month. The black bar in treatment group represented the TN concentrations of water sample when the bioreactor was stopping. 


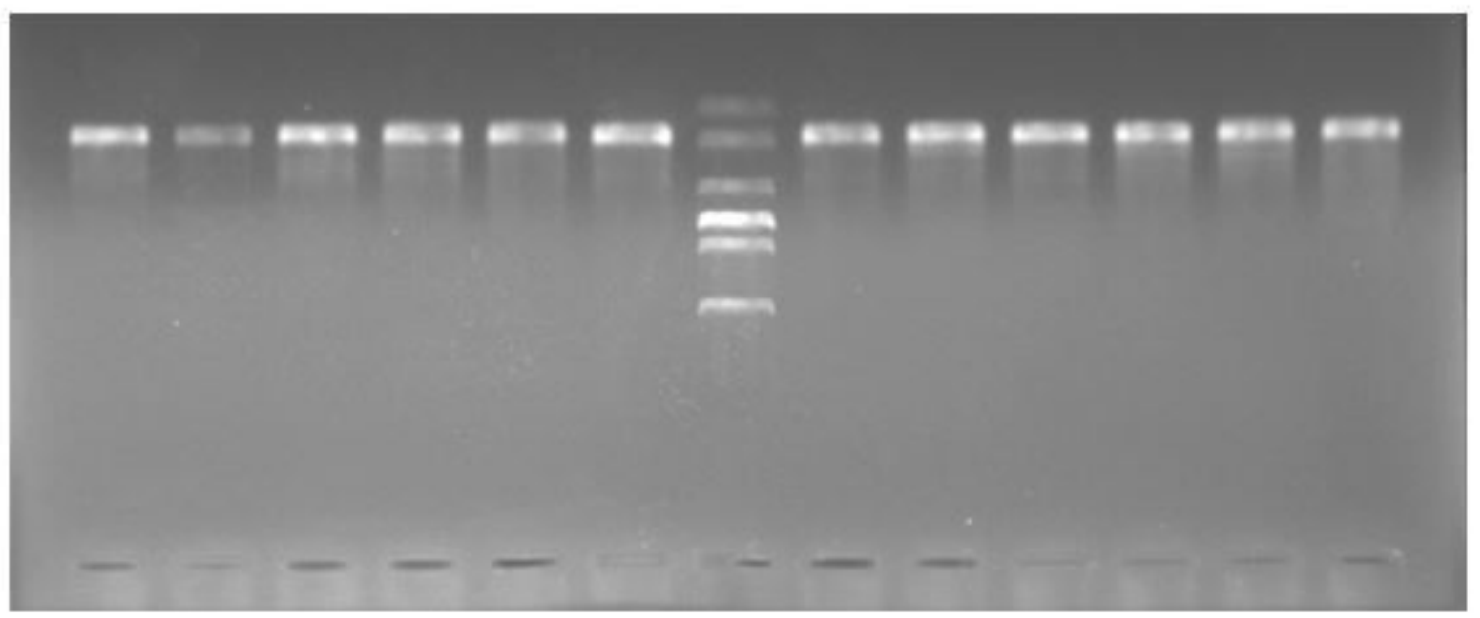

\section{Figure 7}

AGE analysis of the PCR products in MPN culture system of an experiment. The middle band was DNA Marker 2000; the left and right bands were the PCR products of dilution bacteria liquid from 10-1 to 10-6 with + Rpf and -Rpf treatments, respectively. 


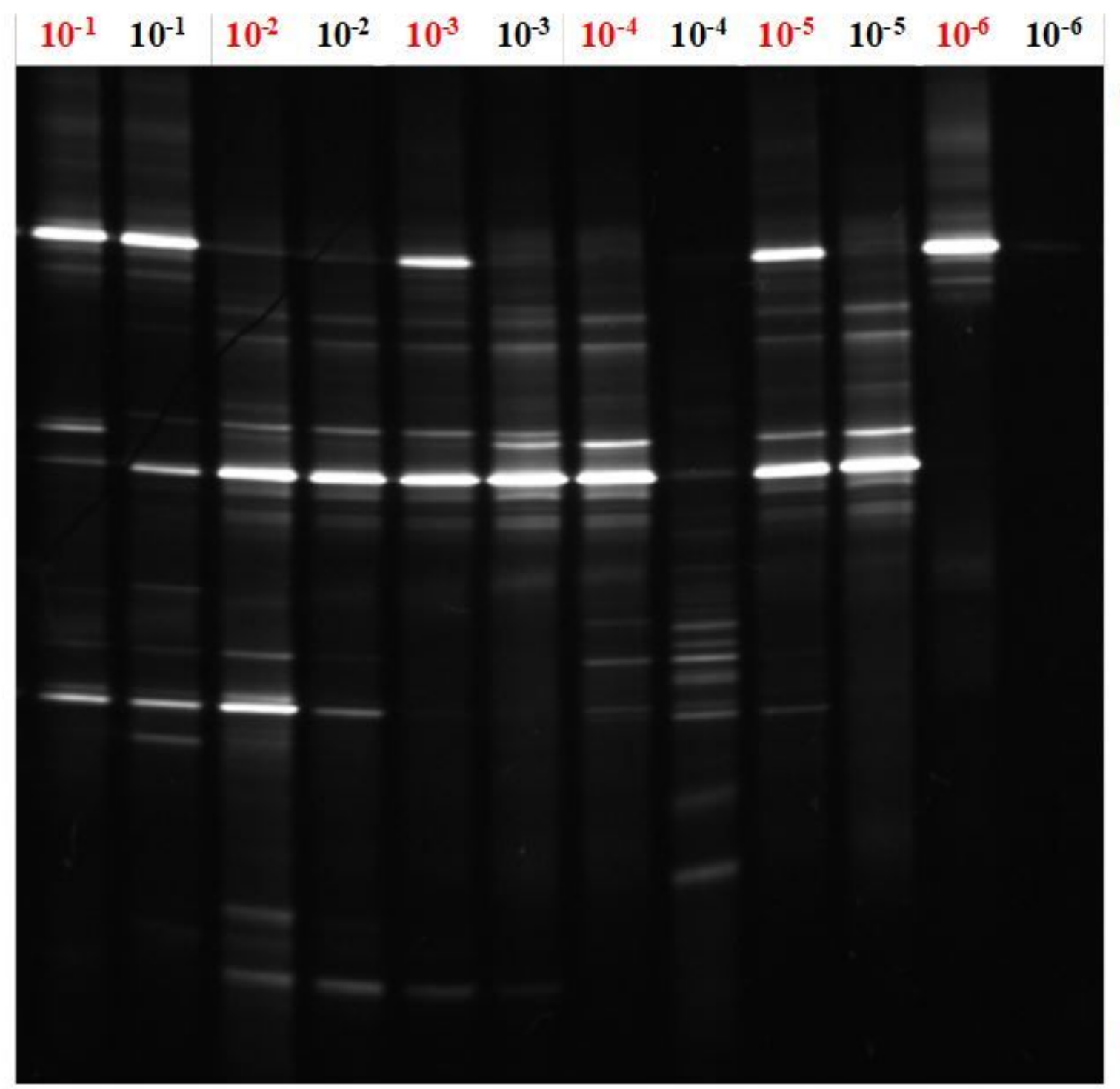

Top

\section{Bottom}

\section{Figure 8}

DGGE profiles of $16 \mathrm{~S}$ rDNA V3 region PCR products (dilution bacteria liquid from10-1 to 10-6). The red 101 to 10-6 represented the dilution bacteria liquid from 10-1 to 10-6 with adding +Rpf treatment; the black 10-1 to 10-6 represented the dilution bacteria liquid from10-1 to 10-6 with adding -Rpf treatment; the blue marked 1 to 10 represented the clear bands for DGGE analysis. 


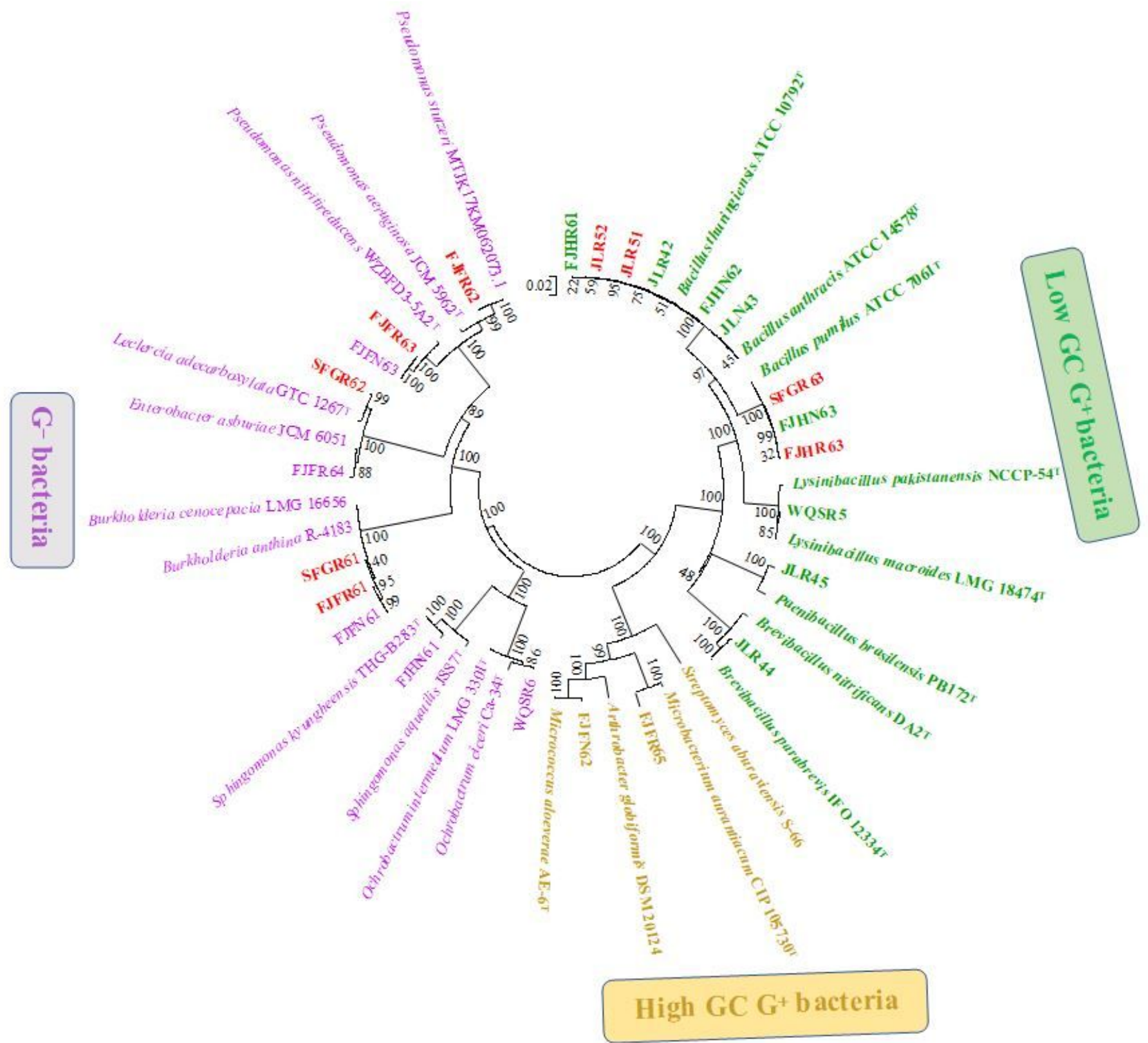

\section{Figure 9}

Phylogenetic tree based on the 16S rRNA gene sequences of isolated strains from the bioreactor. Bootstrap values above $60 \%$ were shown. Bar (0.02) substituted per nucleotide position. Low GC G+ bacteria represented low G + C gram-positive bacteria; High GC G+ bacteria represented high G + C grampositive bacteria; G- bacteria represented gram-negative bacteria; the red marked strains belonged to VBNC bacteria.

\section{Supplementary Files}

This is a list of supplementary files associated with this preprint. Click to download.

- Supplementarymaterial.docx 